\title{
Causes and risk factors for infant mortality in Nunavut, Canada 1999-2011
}

Sorcha A Collins ${ }^{1 \dagger}$, Padma Surmala ${ }^{2+}$, Geraldine Osborne ${ }^{3+}$, Cheryl Greenberg ${ }^{4+}$, Laakkuluk Williamson Bathory ${ }^{5 \dagger}$, Sharon Edmunds-Potvin ${ }^{5+}$ and Laura Arbour ${ }^{1 *+}$

\begin{abstract}
Background: The northern territory Nunavut has Canada's largest jurisdictional land mass with 33,322 inhabitants, of which $85 \%$ self-identify as Inuit. Nunavut has rates of infant mortality, postneonatal mortality and hospitalisation of infants for respiratory infections that greatly exceed those for the rest of Canada. The infant mortality rate in Nunavut is 3 times the national average, and twice that of the neighbouring territory, the Northwest Territories. Nunavut has the largest Inuit population in Canada, a population which has been identified as having high rates of Sudden Infant Death Syndrome (SIDS) and infant deaths due to infections.
\end{abstract}

Methods: To determine the causes and potential risk factors of infant mortality in Nunavut, we reviewed all infant deaths (<1yr) documented by the Nunavut Chief Coroner's Office and the Nunavut Bureau of Statistics ( $\mathrm{n}=117$; 1999-2011). Rates were compared to published data for Canada.

Results: Sudden death in infancy (SIDS/SUDI; 48\%) and infection (21\%) were the leading causes of infant death, with rates significantly higher than for Canada (2003-2007). Of SIDS/SUDI cases with information on sleep position ( $n=42)$ and bed-sharing $(n=47), 29$ (69\%) were sleeping non-supine and $33(70 \%)$ were bed-sharing. Of those bed-sharing, 23 (70\%) had two or more additional risk factors present, usually non-supine sleep position. CPT1A P479L homozygosity, which has been previously associated with infant mortality in Alaska Native and British Columbia First Nations populations, was associated with unexpected infant death (SIDS/SUDI, infection) throughout Nunavut (OR:3.43, 95\% Cl:1.30-11.47).

Conclusion: Unexpected infant deaths comprise the majority of infant deaths in Nunavut. Although the CPT1A P479L variant was associated with unexpected infant death in Nunavut as a whole, the association was less apparent when population stratification was considered. Strategies to promote safe sleep practices and further understand other potential risk factors for infant mortality (P479L variant, respiratory illness) are underway with local partners.

Keywords: Inuit, Nunavut, Aboriginal, Infant mortality, Sudden infant death syndrome, Sudden unexpected death in infancy, Carnitine palmitoyltransferase 1 deficiency, CPT1A P479L variant

\section{Background}

Nunavut, a northern Canadian territory covering the most northern and eastern area of Canada, is Canada's largest jurisdictional land mass with 33,322 inhabitants, of which $85 \%$ self-identify as Inuit $[1,2]$. Nunavut leads the country in adverse early child health outcomes

\footnotetext{
*Correspondence: larbour@uvic.ca

${ }^{\dagger}$ Equal contributors

'Department of Medical Genetics, University of British Columbia Island Medical Program, University of Victoria, PO Box 1700 STN CSC, Victoria, BC V8W 2Y2, Canada

Full list of author information is available at the end of the article
}

such as infant mortality [3], congenital anomalies [4], prematurity, and low birth weight [5,6]. The infant mortality rate in the territory $(14.6 / 1,000$ live births) is three times higher than the national average $(5.2 / 1,000$ live births) and twice that of the Northwest Territories (1999-2009) [3].

An estimated 850 infants are born in Nunavut each year, with $90-95 \%$ of those being born to Inuit women $[2,5]$. There are 25 communities in the three regions of Nunavut: Qikiqtani, Kivalliq and Kitikmeot. Most Nunavut communities are isolated geographically and

\section{Biomed Central}

(c) 2012 Collins et al.; licensee BioMed Central Ltd. This is an Open Access article distributed under the terms of the Creative Commons Attribution License (http://creativecommons.org/licenses/by/2.0), which permits unrestricted use, distribution, and reproduction in any medium, provided the original work is properly cited. 
are accessible only by air and sea. Acute medical care is delivered out of territory in Ontario (Qikiqtani), Manitoba (Kivalliq), and the Northwest Territories (Kitikmeot) $[7,8]$. Approximately $45 \%$ of births to Nunavut residents occur out of territory [9].

In 2010, Luo et al. [10] reported that Sudden Infant Death Syndrome (SIDS) and infection were the leading causes of infant death in Inuit-inhabited regions of Canada between 1990 and 2000. SIDS is a diagnosis of exclusion where the cause of death remains unexplained after a thorough investigation, including a complete autopsy, examination of the death scene, and review of clinical history [11]. Sudden Unexpected Death in Infancy (SUDI) is a broader category that includes unexpected infants deaths with other risk factors present, such as an illness or risk factors for asphyxia [12,13].

The causes of SIDS and SUDI are multi-factorial, due to a combination of environmental, developmental and genetic factors [12-15]. Reducing the risk from one factor may decrease the overall risk of SIDS. Placing infants to sleep on their backs (supine) has substantially reduced SIDS worldwide, apparently over-riding inherent risk factors and reducing risk of asphyxia [13,14]. Results from surveys of Nunavut mothers suggest that only $38-46 \%$ of mothers place their infants to sleep on their backs, compared to $77 \%$ for the rest of Canada $[16,17]$. While it is controversial whether bed-sharing (sharing a sleep surface with an infant) is a risk factor itself, bedsharing is associated with increased risk for SIDS when combined with other risk factors, including non-supine sleep position, bed-sharing with a non-caregiver and bed-sharing with a parent/caregiver who smokes or has impaired arousal $[18,19]$.

Undiagnosed fatty acid oxidation disorders account for $3-6 \%$ of SIDS and SUDI cases [15,20,21]. The P479L (c.1436C > T) genetic variant of the hepatic fatty acid oxidation enzyme, carnitine palmitoyltransferase 1A (CPT1A), has been associated with infant mortality in Alaska Native and British Columbia coastal First Nations populations, where the variant is common [22,23]. In 2010, we established that the CPT1A P479L variant is highly prevalent in Nunavut; more than $70 \%$ of infants born in Kitikmeot and Kivalliq regions of Nunavut were P479L homozygous $(n=290 ; 2006)$ [24]. To date, the P479L variant has only been reported in Indigenous populations [24,25]. Importantly, the variant has also been reported to confer positive effects in studies of cardiovascular lipid profiles and obesity $[25,26]$. It remains controversial whether the variant is a risk factor itself for infant mortality or a marker of other population-based risk factors more common in high prevalence areas.

Reducing infant mortality is a primary goal of the 2008-2013 Government of Nunavut Public Health Strategy, Developing Healthy Communities [27]. In keeping with the goal of developing programs to reduce infant mortality in Nunavut, we report the causes and associated risk factors in Nunavut from 1999-2011, using data from the Nunavut Chief Coroner's Office, Nunavut Bureau of Statistics and Statistics Canada [28]. We also compare Nunavut rates to published national data for similar years available through the Public Health Agency of Canada [29].

\section{Methods}

\section{Ethics}

Ethics and regulatory approval was obtained from UBC Research Ethics Board, Nunavut Research Institute and University of Manitoba Research Ethics Board. The review was conducted in partnership with Nunavut Tunngavik Inc.

\section{Data sources}

All infant deaths (live birth with death before 1 year of age) occurring in Nunavut between July 1, 1999 and June 30, 2011 and reported to the Nunavut Chief Coroner's Office and, subsequently, to the Nunavut Chief Medical Officer of Health, were reviewed. Infant deaths recorded by the Nunavut Bureau of Statistics were also reviewed. This dataset captured all postneonatal infant death and a subset of neonatal death. Early neonatal deaths for those infants born out of territory where death occurred before registration in Nunavut were not commonly available. Consequently, ascertainment of perinatal and neonatal deaths was limited for this review. All prenatally occurring deaths (stillbirths) were excluded from this review.

Variables collected (when available) were: date of birth, date of death, cause of death, gender, gestational age at birth, mother's place of residence at time of death, CPT1A P479L genotype, and sleep environment (i.e. sleep position, sleep surface, loose bedding, bed-sharing). Sleep environment was obtained from death scene investigation report. Bed-sharing was defined as those infants sharing a sleep surface with another person as documented when the death occurred. Causes of death were as determined by the Chief Coroner after review of autopsy reports and death scene investigation. Cases were grouped into one of four major cause of death categories; SIDS/ SUDI, infection (respiratory, $\mathrm{H}$ influenza or other), congenital anomaly or other.

Data for live births to mothers residing in Nunavut for July 1, 1999-June 30, $2011(n=9215)$ were obtained from Statistics Canada [28]. National comparison data for infant deaths (1998-2007) were obtained from the Public Health Agency of Canada 2011 Perinatal Health Indicators for Canada report [29].

When available, CPT1A genotype data for the P479L variant was collected for unexpected infant death cases 
(SIDS/SUDI and death due to infection) where suboptimal CPT1A function might influence outcome. There were 81 unexpected infant death cases during the review period and CPT1A P479L genotype information was available for 35 cases. In 2004, the Manitoba Newborn Screening program commenced a pilot CPT1A P479L newborn screening program for infants born to Kivalliq region residents [30]. Eighteen of the 35 identified cases had been previously genotyped during routine newborn screening as part of that pilot project. The remaining 17 were genotyped on request of the Chief Coroner or pathologist performing the autopsy. Our previously reported data for CPT1A P479L genotypes in infants born to Nunavut residents in $2006(n=695)$ were used for comparison [24].

\section{Data analysis}

Crude mortality rates were calculated per 1,000 live births by region and for Nunavut [28,31]. Nunavut rates were compared to Canadian data using odds ratios with 95\% confidence intervals (CI). Crude national infant and postneonatal mortality rates were calculated with available 1998-2007 data, and crude national cause-specific mortality rates were calculated with available 2003-2007 data. National rates exclude Ontario [29].

Association (odds ratios with 95\% CI) of the P479L variant with unexpected infant death (SIDS, SUDI and infection) was analysed by comparing P479L homozygous cases to the population P479L homozygosity, as estimated for live born infants undergoing newborn screening in Nunavut in 2006 [24]. Population data were analysed by comparing P479L homozygosity between regions using $\chi^{2}$ test with a $p<0.05$ significance level. Hardy-Weinberg equilibrium was previously calculated [24].

All statistical analysis was conducted using STATA 11 (StataCorp. 2009. Stata Statistical Software: Release 11. College Station, TX). Two-tailed $p$ values $<0.05$ were considered significant. Due to limited information, risk associated with sleep practices could not be analysed. Information on maternal and household characteristics, including parity, maternal age, maternal education, household income and food security, were very limited or not available for this review.

\section{Results}

There were 117 infant mortality cases documented in Nunavut between 1999 and 2011. Ninety infant deaths occurred in Nunavut and were reported to the Chief Coroner. An additional 27 cases were reported to the Nunavut Bureau of Statistics, 7 of which occurred in the territory during the perinatal period (all occurred on the first day of life); the remaining 20 occurred out of territory (Edmonton, Winnipeg and Ottawa). Cause of death was documented for 95 cases.

The leading causes of infant death were SUDI $(n=32$; $27 \%)$, SIDS $(n=24 ; 21 \%)$ and infection $(n=25 ; 21 \%)$. Combined, SIDS and SUDI (SIDS/SUDI) comprised the majority of cases (48\%). Cause-specific infant mortality rates for SIDS/SUDI and infections were 6.08 and 2.71/1,000 live births, respectively, and these rates were significantly increased compared to national rates (ORs:11.97; 95\%CI: 8.9-15.8 and 8.79; 95\%CI: 5.6-13.2; Table 1). Cause specific mortality rates for SIDS/SUDI

Table 1 Age and cause specific mortality rates (per 1,000 live births) for infant deaths documented in Nunavut by region ( $n=117$; July 1 1999-June 302011 ) and in Canada ${ }^{\dagger}$ (1998-2007)

\begin{tabular}{|c|c|c|c|c|c|c|}
\hline & \multicolumn{4}{|c|}{ Nunavut IMR $(95 \% \mathrm{CI})^{*}$} & \multirow{2}{*}{$\begin{array}{l}\text { Canada }{ }^{\dagger} \text { IMR } \\
(95 \% \mathrm{CI})\end{array}$} & \multirow{2}{*}{$\begin{array}{l}\text { Odds Ratio } \\
(95 \% \mathrm{Cl})\end{array}$} \\
\hline & Qikiqtani & Kivalliq & Kitikmeot & Nunavut & & \\
\hline Live births & 4,859 & 2,817 & 1,539 & 9,215 & $1,065,647$ & \\
\hline \multicolumn{7}{|l|}{ Mortality Rates } \\
\hline Infant death & $10.91(8.18-14.24)$ & $13.13(9.26-18.06)$ & $16.89(11.06-24.66)$ & $12.70(10.51-15.20)$ & $5.15(5.01-5.28)$ & $2.47(2.04-2.98)$ \\
\hline Postneonatal death & $8.23(5.89-11.19)$ & $10.65(7.20-15.17)$ & $11.70(6.95-18.42)$ & $9.66(7.76-11.87)$ & $1.39(1.31-1.46)$ & $6.96(5.56-8.64)$ \\
\hline \multicolumn{7}{|l|}{ Cause of Death } \\
\hline SIDS and SUDI & $5.76(3.83-8.32)$ & $5.68(3.25-9.21)$ & $7.80(4.04-13.58)$ & $6.08(4.59-7.88)$ & $0.51(0.47-0.55)$ & $11.97(8.92-15.79)$ \\
\hline Infection & $2.06(0.99-3.78)$ & $3.19(1.46-6.06)$ & $3.25(1.06-7.57)$ & $2.71(1.76-4.00)$ & $0.31(0.28-0.34)$ & $8.79(5.60-13.21)$ \\
\hline Respiratory & $0.82(0.22-2.11)$ & $0.71(0.09-2.56)$ & $1.95(0.40-5.69)$ & $1.63(0.91-2.68)$ & - & - \\
\hline $\mathrm{H}$ influenza & $0.41(0.05-1.49)$ & $0.36(0.01-1.98)$ & $1.30(0.16-4.69)$ & $0.65(0.24-1.42)$ & - & - \\
\hline Other & $0.82(0.22-2.11)$ & $0.00(0.00-1.31)$ & $0.00(0.00-2.39)$ & $0.43(0.12-1.11)$ & - & - \\
\hline Congenital anomalies & $0.41(0.05-1.49)$ & $0.36(0.01-1.98)$ & $1.30(0.16-4.69)$ & $0.54(0.18-1.27)$ & $1.19(1.13-1.26)$ & $0.46(0.15-1.07)$ \\
\hline
\end{tabular}

* Crude mortality rates for Nunavut were calculated per 1,000 live births.

+ Canadian rates (excluding Ontario) of crude infant and postneonatal mortality were calculated with available 1998-2007 data and cause-specific mortality were calculated with available 2003-2007 data, as reported by the Public Health Agency of Canada in the Perinatal Health Indicators for Canada 2011 report [29]. $I M R=$ infant mortality rate. $\mathrm{Cl}=$ confidence interval. 
and respiratory infections were higher in the Kitikmeot region than in the Kivalliq and Qikiqtani regions.

Postneonatal deaths (28-364 days) accounted for $76 \%$ $(n=89)$ of all infant deaths in this review. The crude postneonatal mortality rate for Nunavut was 9.66/1,000 live births, significantly higher than the national rate of $1.39(\mathrm{OR}=6.96$, 95\%CI: 5.56-8.64). SIDS/SUDI $(\mathrm{n}=52$, $58 \%)$ and infection $(\mathrm{n}=22,25 \%)$ were the leading causes of postneonatal death in Nunavut (Figure 1).

\section{SIDS and SUDI risk factors}

There were 56 SIDS and SUDI cases during the review period; $86 \%$ occurred before 6 months of age. Deaths were evenly distributed between genders (male $=29$, female $=27$ ). Gestational age at birth was available for 41 cases, $14(25 \%)$ were born premature $(<37$ completed weeks of gestation).

Some information on sleep environment at time of death was available for 52 of the 56 SIDS/SUDI cases. Two or more sleep environment risk factors were documented in 39 cases (70\%). Of those cases with documented sleep position at time of death $(n=42)$, sleep position was non-supine for 29 (69\%). Bed-sharing occurred in 33 of the 47 cases $(70 \%)$ with that information. Of the 33 cases known to be bed-sharing at time of death, $23(70 \%)$ had two or more additional risk factors present, including non-supine sleep position, sleeping on a soft surface (sofa), bed-sharing with a non-caregiver, and/or smoking or alcohol/illicit drug use by bed-sharer.

\section{Death due to infection}

Death due to infection was the cause of death for 25 cases. The majority of deaths were due to respiratory infection $(\mathrm{n}=15)$ or Haemophilus influenzae infection (type a or b; $\mathrm{n}=6$ ). Two Haemophilus influenzae cases had a respiratory component. The remaining infectious causes included herpes simplex virus, granulomatous encephalitis, sepsis and viral myocarditis.

\section{Prematurity}

Gestational age was available for 75 of the total infant mortality cases, of those, 29 (39\%) were born premature ( $<37$ completed weeks of gestation), representing $25 \%$ of our total review.

\section{CPT1A P479L variant and unexpected infant death}

CPT1A genotypes were available for 35 of the 81 unexpected infant deaths (SIDS/SUDI or infection) during the review period. Of the 35 cases with genotype, 30 were P479L homozygous and the remaining 5 were heterozygous. All SIDS/SUDI cases with CPT1A genotype data (17 P479L homozygous and 5 heterozygous) had other risk factors for sudden death present, including nonsupine sleep position and/or bed-sharing at time of death. All infectious death cases were homozygous (8 respiratory and 5 Haemophilus influenzae).

P479L homozygosity was associated with unexpected infant death in Nunavut with all regions combined (OR: 3.43, 95\%CI: 1.30-11.47; Table 2). Population based P479L homozygosity was significantly higher in the Kitikmeot and Kivalliq regions compared to the Qikiqtani region $\left(x^{2}=22.86, p<0.0001\right)$, suggesting population stratification in the Qikiqtani region, where the variant is not in Hardy-Weinberg equilibrium [24]. There was no statistical difference in homozygosity between the Kivalliq and Kitikmeot regions.

\section{Discussion}

Indigenous populations worldwide experience infant and postneonatal mortality rates that are substantially higher than national averages [10,32-34]. This is true in the Inuit regions of Canada, including the Nunavut territory, where infant mortality rates are consistently 3 times the national rate $[3,10]$. Our review suggests an overall crude infant mortality rate slightly lower than reported previously, likely due to under ascertainment of neonatal deaths. However, postneonatal mortality rates were consistent with or higher than previous reports $[3,10]$.

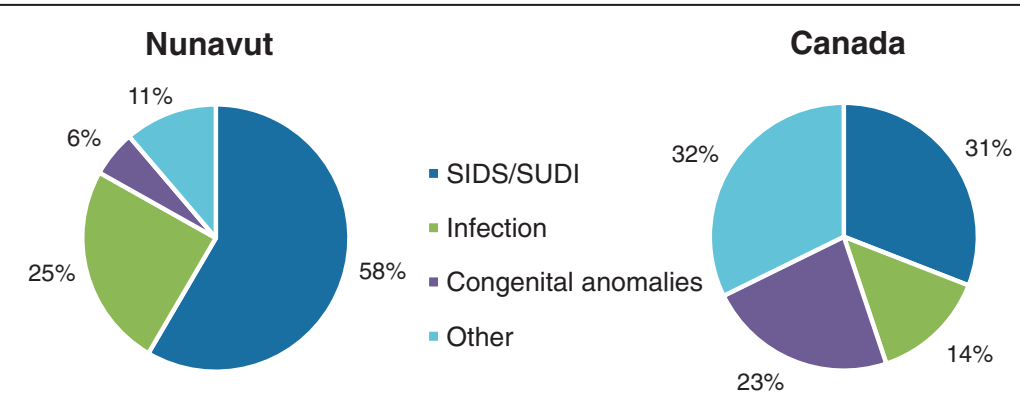

Figure 1 Causes of Postneonatal Death in Nunavut (July 1 1999-June 30 2011; n=89) and Canada (excludes Ontario; 2003-2007; $\mathrm{n}=\mathbf{1 4 7 8}$ [29]. Infection includes deaths due to respiratory or other infections. 
Table 2 Comparison of CPT1A P479L homozygosity in unexpected infant death cases (SIDS, SUDI and infection) occurring in Nunavut (July 1, 1999-June 30, 2011) to the estimated population P479L homozygosity [24], by region and territory

\begin{tabular}{|c|c|c|c|c|c|c|c|c|c|}
\hline & \multicolumn{3}{|c|}{ Cases } & \multicolumn{3}{|c|}{ Population } & \multirow{2}{*}{$\begin{array}{l}\text { Odds } \\
\text { Ratio }\end{array}$} & \multirow[t]{2}{*}{$(95 \% \mathrm{Cl})$} & \multirow{2}{*}{$\begin{array}{l}2 \text { sided } \\
\text { FET } p\end{array}$} \\
\hline & $\mathrm{n}$ & $f$ & $(95 \% \mathrm{Cl})$ & $n$ & $f$ & $(95 \% \mathrm{Cl})$ & & & \\
\hline NUNAVUT & 30 & 85.7 & $(69.7-95.2)$ & 442 & 63.6 & $(59.9-67.2)^{*}$ & 3.43 & $(1.30-11.47)$ & 0.006 \\
\hline Qikiqtani & 8 & 88.9 & $(51.8-99.7)$ & 162 & 53.6 & $(47.8-59.4)^{*}$ & 6.91 & $(0.90-308.87)$ & 0.044 \\
\hline Kivalliq & 16 & 88.9 & $(62.5-98.6)$ & 170 & 70.0 & $(63.8-75.7)$ & 3.44 & $(0.77-31.45)$ & 0.108 \\
\hline Kitikmeot & 6 & 75.0 & (34.9-96.8) & 110 & 73.3 & $(65.5-80.2)$ & 1.09 & $(0.19-11.47)$ & 1.000 \\
\hline Kivalliq \& Kitikmeot (combined) & 22 & 84.6 & $(65.1-95.6)$ & 290 & 71.2 & $(66.5-75.7)$ & 2.22 & $(0.73-9.04)$ & 0.178 \\
\hline
\end{tabular}

* Genotype frequencies deviated from Hardy-Weinberg equilibrium ( $p<0.05$ ) [24].

$f=$ frequency. $C l=$ confidence interval. $F E T=$ fisher's exact test.

SIDS and deaths due to infections have been previously identified as the leading contributors to the higher rates of postneonatal mortality in indigenous populations of Western Australia and Alaska [33,34]. In this review, Nunavut rates of SIDS/SUDI $(6.08 / 1,000)$ and infection $(2.71 / 1,000)$ were significantly higher than national rates (2003-2007) and consistent with those previously reported for Inuit-inhabited regions of Canada (1990-2000) [10]. Additionally, the high rate of SIDS/ SUDI in this review is consistent with or higher than those reported for indigenous populations in Western Australia (4.7/1,000; 1998-2001) and Alaska (3.6/1,000; 2000-2003) [33,34].

\section{Sleep environment in SIDS and SUDI cases}

We report a SIDS/SUDI rate for Nunavut that is significantly higher than the national rate $(\mathrm{OR}=11.97,95 \% \mathrm{CI}$ : 8.92-15.79). Review of sleep environment at time of death showed $70 \%$ of SIDS/SUDI cases had two or more sleep-related risk factors present. Importantly, nonsupine sleep position was present in $69 \%$ of cases with sleep-position documented, emphasizing the need for improved safe sleep messaging in Nunavut.

Bed-sharing was also prevalent in SIDS/SUDI cases (70\% of those with bed-sharing information); however, a majority of cases bed-sharing at time of death had additional sleep-related risk factors present, including non-supine sleep position and/or bed-sharing with non-caregiver(s). This is consistent with the 2006 Aboriginal Children's survey that reports caregivers of Inuit infants are less likely to place the infant supine for sleep when bed-sharing [16].

Although our data are limited, our results are consistent with other studies that suggest bed-sharing with additional risk factors present increases risk for SIDS/SUDI $[18,19]$. In cultures such as the Inuit culture, where mothers traditionally and continue to prefer to bed-share with infants, advising against bed-sharing under all circumstances may not be easily accepted. Health promotion strategies must consider cultural perspectives and a strong emphasis on risk reduction is crucial [35]. Better information regarding infant sleep practices in the overall population and at time of death is needed to assess risk effectively. In our review, many SIDS/SUDI case reports did not include full information on sleep environment at time of death.

\section{Infection}

Infection was the second leading cause of infant mortality during the review period, and had a cause specific mortality rate of 2.71/1,000 live births. Respiratory infection comprised the majority of cases. Infants in Nunavut have the highest reported rate of hospitalisation for lower respiratory tract infections worldwide, with an average of 306-484/1,000 infants [36,37]. The hospitalization rate for infants with heart defects is even higher at 800/1,000 infants. Prematurity, tobacco smoke exposure (prenatal and postnatal), overcrowding and poor ventilation are all risk factors for respiratory infections and hospital admissions for Inuit children living in Nunavut $[37,38]$. Although tobacco smoke exposure data were limited in this review, environmental tobacco smoke is reported to be present in $\sim 90 \%$ of Nunavut homes, which are small, overcrowded and have low air change rates [39].

Haemophilus influenzae infection (type a or b) was the cause of death for 6 cases during the review period. The International Circumpolar Surveillance system reports that northern Canada has the highest rate of invasive Haemophilus influenzae type A in children under the age of two in the circumpolar region (1999-2006) [40]. From 2009-2010, there were 11 cases under age 2 confirmed in Nunavut (G Osborne, personal communication).

\section{Prematurity}

Nunavut has an average preterm birth rate of $12 \%$, which is 1.5 times the Canadian average of $8 \%$ [31]. Infants born premature have a 3-6 times higher risk of mortality than term infants, including higher risks for deaths due to SIDS and infections [41,42]. Premature infants comprised at least $25 \%$ of the infant mortality 
cases in this review. This is likely an underestimate since the early neonatal deaths occurring out of territory were not available for review. High levels of prenatal exposure to cigarette smoke increases the risk of premature birth $[41,43]$. Although prenatal maternal smoking was not well documented in the data available for this review, in other studies $60-80 \%$ of Nunavut women self-reported smoking during pregnancy, almost 5 times the national average of $13 \%$ [43,44]. Mothers who reported smoking greater than 10 cigarettes per day during pregnancy had twice the risk of having a premature infant than those who did not smoke [43].

\section{P479L CPT1A homozygosity in unexpected infant death cases}

CPT1A is an important liver enzyme required to transport long chain fatty acids into the mitochondrion for use as energy when dietary carbohydrates are unavailable (i.e. during fasting or prolonged exercise). CPT1A deficiency is a rare autosomal recessive disorder, usually presenting in infancy as non-ketotic hypoglycemia and metabolic decompensation triggered by fasting, which can progress to seizures, brain damage, and sudden death [45]. A small number of Nunavut Inuit infants and children, homozygous for the CPT1A P479L variant, have presented symptomatically with features consistent with CPT1A deficiency or with sudden unexpected death [30].

In our review, P479L homozygosity was associated with unexpected infant death (SIDS/SUDI and infection) in Nunavut as a whole (OR 3.43, 95\%CI:1.30-11.47; $\mathrm{p}=0.006$ ), which is consistent with results reported for Alaska Native and British Columbia First Nations populations [22,23]. However, analysis of the 2006 population data by region determined that the background prevalence of P479L homozygosity was significantly lower in the Qikiqtani region. Although underpowered, the association of P479L homozygosity with unexpected infant death was less apparent in the high prevalence regions, especially in the Kitikmeot region (OR: 1.09, 95\% CI: 0.19-11.47), which had the highest rates of postneonatal mortality, SIDS/SUDI and infant death due to infection.

Although the overall population of Nunavut is small $(\sim 33,000)$ and the regions often combined, rates of immigration and emigration differ between the Nunavut regions [46]. Population stratification leading to spurious results is a particular concern in genetic association studies, especially when geographic sub-sets of small populations are being evaluated. The significantly lower P479L homozygosity in the Qikiqtani region may be due to admixture and/or a higher rate of non-Inuit immigration from other regions and provinces. Combining all regions increases the likelihood of a statistically significant difference if the case population rate is not entirely reflective of the reference population. Indeed, all postneonatal deaths in our review were born to Inuit mothers, which may have a higher homozygosity rate than the whole Qikiqtani region.

At this time we cannot rule out or confirm an associated risk with the P479L allele given our small numbers. Further study, controlling more precisely for population stratification is indicated. It remains possible that the association between the variant and unexpected infant death represents a complex interaction of the variant with environmental risk factors including sleep position, bed-sharing, prenatal and postnatal tobacco smoke exposure and food security. The 'triple risk hypothesis' for SIDS proposes that an external stressor combines with an underlying vulnerability at a critical development period to cause a SIDS death [47]. The P479L variant may represent an underlying vulnerability (i.e. a predisposition to hypoglycemia) that, when combined with exogenous stressors during a critical development period and/or intercurrent illness, may increase risk for unexpected infant death.

Alternatively, it is possible that the variant when homozygous serves as a marker of other social, economic, cultural or biological factors which increase the risk for infant mortality. There is suggestion of protective effect for cardiovascular lipid profiles and obesity in the Alaska Yupik and Greenland Inuit adults, perhaps in the context of a traditional diet $[25,26]$. Given the high frequency of the variant in Inuit populations pointing to an historical advantage, the current clinical significance of the variant remains unclear.

\section{Limitations}

This was a retrospective case review with incomplete risk determinant information. Most mortality subgroups presented in this review were too small for complex statistical analysis. Full ascertainment for CPT1A P479L genotype, sleep position and bed-sharing was not possible. Ongoing study is needed to confirm these baseline results.

Our review was limited to those cases documented in Nunavut by the Chief Coroner's Office and the Nunavut Bureau of Statistics, therefore our dataset underrepresented deaths of cases born out of territory, especially with death during the first hospitalization (for example extreme prematurity and severe congenital anomalies). Therefore it is expected that the neonatal mortality rate is lower in our study than reported elsewhere $[3,10]$.

Information on socioeconomic status (SES), including maternal education, household income and food security, were not available for this review. This may be an important limitation because of the known association with low socioeconomic status and infant mortality [48]. 
Of particular concern for this population are the results from the recent Inuit Health Survey showing that almost $70 \%$ of Nunavut households with preschoolers are either moderately or severely food insecure, which is more than 7 times the national average (9\%) [49]. On-going research will address this limitation.

\section{Conclusion}

Consistent with a previous study of Inuit birth outcomes in Canada [10], our study suggests a greater proportion of infants in Nunavut die of SIDS, SUDI or infection than infants in the rest of Canada. Factors such as sleep position and bed-sharing may play a role in these deaths. Although the P479L variant was associated with unexpected infant death in Nunavut as a whole, the association was less apparent when population stratification was considered. Population stratification as an underlying determinant of this association needs further assessment, as does the association of other potentially interactive risk factors. Prospective study of the health outcomes for P479L homozygous infants is planned to clarify the variant's role in the health of these individuals, and the impact, if any, that treatment may have on these health outcomes.

Improved prenatal and postnatal data collection would enhance the understanding of the increased rates of infant mortality and inform prevention strategies. Efforts to improve maternal child health surveillance are now underway [50]. On-going assessment of the multiple risk factors involved in infant mortality will inform public health policy and prevention. Information regarding sleep position needs to be better communicated in a culturally appropriate manner. Messaging about infant care and sleep practices should come from within communities as well as from health care providers.

\section{Abbreviations \\ CPT1A: Carnitine palmitoyltransferase 1A; Cl: Confidence interval; SIDS: Sudden infant death syndrome; SUDI: Sudden unexpected death in infancy.}

\section{Competing interests}

The authors declare that they have no competing interests.

\section{Authors' contributions}

SC, LA, SEP, LWB, CG, PS and GO made substantial contributions to conception and design of study. SC, PS, CG and GO participated in the acquisition of data. SC conducted statistical analysis and drafted and revised the manuscript. LA and GO participated in analysis and interpretation of data and revision of the manuscript. All authors read and approved the final manuscript.

\section{Acknowledgements}

The authors would like to thank Samantha Lauson, MSc and Sarah Mclntosh, MSc (Dept of Medical Genetics, UBC), Tim Neily (former Chief Coroner, Nunavut), and Dr. Isaac Sobol (former Chief Medical Officer of Health, Nunavut). This research was funded by CIHR team grant on circumpolar health (CIHR-CTP-78953) to T. Kue Young and L. Arbour and by Health Canada (HQ1100083) to L. Arbour and G. Osborne. The views expressed herein are solely those of the authors and do not necessarily reflect the official position of Health Canada. L. Arbour is funded through a Michael Smith Foundation for Health Research Scholar Award.

\section{Author details}

${ }^{1}$ Department of Medical Genetics, University of British Columbia Island Medical Program, University of Victoria, PO Box 1700 STN CSC, Victoria, BC V8W 2Y2, Canada. ${ }^{2}$ Court Services Division, Department of Justice, Government of Nunavut, Iqaluit, NU, Canada. ${ }^{3}$ Department of Health and Social Services, Government of Nunavut, lqaluit, NU, Canada. ${ }^{4}$ Department of Pediatrics and Child Health, University of Manitoba, Winnipeg, MB, Canada.

${ }^{5}$ Nunavut Tunngavik Incorporated, Iqaluit, NU, Canada.

Received: 13 September 2012 Accepted: 5 December 2012

Published: 12 December 2012

\section{References}

1. Statistics Canada: Table 051-0001 - Estimates of population, by age group and sex for July 1, Canada, provinces and territories, annual (persons unless otherwise noted), CANSIM (database);; 2012 [http://www5.statcan.gc.ca/ cansim/a26?lang=eng\&retrLang=eng\&id=0510001\&paSer=\&pattern=\&stByVal= $1 \& \mathrm{p} 1=1 \& \mathrm{p} 2=-1 \&$ tabMode $=$ dataTable\&csid $=]$

2. Statistics Canada: Aboriginal Peoples in Canada in 2006: Inuit, Métis and First Nations, 2006 census: findings.; 2008. Catalogue no. 97-558-XIE. [http:// www12.statcan.ca/census-recensement/2006/as-sa/97-558/index-eng.cfm? CFID $=78991 \&$ CFTOKEN=71134813]

3. Statistics Canada: Table 102-0507 - Infant mortality, by age group, Canada, provinces and territories, annual, CANSIM (database).; 2012 [http://www5. statcan.gc.ca/cansim/a26?lang=eng\&retrLang=eng\&id=1020507\&paSer $=$ \&pattern=\&stByVal=1\&p1=1\&p2=-1\&tabMode=dataTable\&csid=]

4. Arbour L, Gilpin C, Millor-Roy V, Platt R, Pekeles G, Egeland GM, Hodgins S, Eydoux P: Heart defects and other malformations in the Inuit in Canada: a baseline study. Int J Circumpolar Health 2004, 63:251-266.

5. Muggah E, Way D, Muirhead M, Baskerville B: Preterm delivery among Inuit women in the Baffin Region of the Canadian Arctic. Int J Circumpolar Health 2004, 63(Suppl 2):242-247.

6. Statistics Canada: Table 102-4304 - Birth-related indicators (low and high birth weight, small and large for gestational age, pre-term births), by sex, three-year average, Canada, provinces, territories, census metropolitan areas and metropolitan influence zones, occasional (number unless otherwise noted), CANSIM (database).; 2011 [http://www5.statcan.gc.ca/cansim/a26?lang=eng\& retrLang=eng\&id=1024304\&paSer=\&pattern=\&stByVal=1\&p1=1\&p2=-1\& tabMode $=$ dataTable\&csid $=$ ]

7. Creery D, Lyer P, Samson L, Coyle D, Osborne G, MacDonald A: Costs associated with infant bronchiolitis in the Baffin region of Nunavut. Int J Circumpolar Health 2005, 64:38-45.

8. Young TK: Northern Canada, Health Transitions in Arctic Populations. Toronto: University of Toronto Press; 2008:39-52.

9. Statistics Canada: Table 102-4501 - Live births, by place of residence of mother and place of occurrence, Canada, provinces, territories and outside Canada, annual (number), CANSIM (database):; 2011 [http://www5.statcan.gc.ca/ cansim/a26?lang=eng\&retrLang=eng\&id=1024501\&paSer=\&pattern=\&stByVal= $1 \&$ p1 =1\&p2=-1\&tabMode=dataTable\&csid $=$ ]

10. Luo Z-C, Senecal S, Simonet F, Guimond E, Penney C, Wilkins R: Birth outcomes in the Inuit-inhabited areas of Canada. CMAJ 2010, 182:235-242.

11. Willinger $M$, James $L S$, Catz C: Defining the sudden infant death syndrome (SIDS): deliberations of an expert panel convened by the National Institute of Child Health and Human Development. Pediatr Pathol 1991, 11:677-684.

12. Moon RY, Horne RSC, Hauck FR: Sudden infant death syndrome. Lancet 2007, 370:1578-1587.

13. Kinney HC, Thach BT: The sudden infant death syndrome. N Engl J Med 2009, 361:795-805

14. Canadian Paediatric Society: Recommendations for safe sleeping environments for infants and children. Paediatr Child Health 2004, 9:659-663.

15. Olpin SE: The metabolic investigation of sudden infant death. Ann Clin Biochem 2004, 41:282-293.

16. Asuri S, Ryan A, Arbour L: Looking to the Future: Report on prevention of SIDS in Inuit regions. Inuit Tapiriit Kanatami (ITK): UBC; 2011. 
17. Public Health Agency of Canada: What Mothers Say: The Maternity Experiences Survey. Ottawa:; 2009 [http://www.phac-aspc.gc.ca/rhs-ssg/ survey-eng.php]

18. Blair PS, Platt MW, Smith IJ, Fleming PJ: Sudden infant death syndrome and sleeping position in pre-term and low birth weight infants: an opportunity for targeted intervention. Arch Dis Child 2006, 91:101-106.

19. Horsley T, Clifford T, Barrowman N, Bennett S, Yazdi F, Sampson M, Moher $D$, Dingwall $O$, Schachter $H$, Cote $A$ : Benefits and harms associated with the practice of bed sharing: a systematic review. Arch Pediatr Adolesc Med 2007, 161:237-245

20. Chace DH, DiPerna JC, Mitchell BL, Sgroi B, Hofman LF, Naylor EW: Electrospray tandem mass spectrometry for analysis of acylcarnitines in dried postmortem blood specimens collected at autopsy from infants with unexplained cause of death. Clin Chem 2001, 47:1166-1182.

21. Boles RG, Buck EA, Blitzer MG, Platt MS, Cowan TM, Martin SK, Yoon H Madsen JA, Reyes-Mugica M, Rinaldo P: Retrospective biochemical screening of fatty acid oxidation disorders in postmortem livers of 418 cases of sudden death in the first year of life. J Pediatr 1998, 132:924-933.

22. Gessner BD, Gillingham MB, Birch S, Wood T, Koeller DM: Evidence for an association between infant mortality and a carnitine palmitoyltransferase 1 A genetic variant. Pediatrics 2010, 126:945-951.

23. Sinclair GB, Collins S, Popescu O, McFadden D, Arbour L, Vallance HD: Carnitine palmitoyltransferase $I$ and sudden unexpected infant death in British Columbia First Nations. Pediatrics 2012, 130:e1162-e1169.

24. Collins SA, Sinclair G, Mclntosh S, Bamforth F, Thompson R, Sobol I, Osborne G, Corriveau A, Santos M, Hanley B, Greenberg CR, Vallance $H$, Arbour L: Carnitine palmitoyltransferase 1A (CPT1A) P479L prevalence in live newborns in Yukon, Northwest Territories, and Nunavut. Mol Genet Metab 2010, 101:200-204.

25. Rajakumar C, Ban MR, Cao H, Young TK, Bjerregaard P, Hegele RA: Carnitine palmitoyltransferase IA polymorphism P479L is common in Greenland Inuit and is associated with elevated plasma apolipoprotein A-I. J Lipid Res 2009, 50:1223-1228.

26. Lemas DJ, Wiener HW, O'Brien DM, Hopkins S, Stanhope KL, Havel PJ, Allison DB, Fernandez JR, Tiwari HK, Boyer BB: Genetic polymorphisms in carnitine palmitoyltransferase $1 \mathrm{~A}$ gene are associated with variation in body composition and fasting lipid traits in Yup'ik Eskimos. J Lipid Res 2012, 53:175-184.

27. Government of Nunavut Department of Health and Social Services: Developing Healthy Communities: A Public Health Strategy for Nunavut. Iqaluit, Nunavut: Government of Nunavut; 2008:2008-2013.

28. Statistics Canada: Table 051-0054 - Births by census division and sex for the period from July 1 to June 30, based on the Standard Geographical Classification (SGC) 2006, annual (persons), CANSIM (database):; 2012 [http:// www5.statcan.gc.ca/cansim/a26?lang=eng\&retrLang=eng\&id=0510054\&paSer= \&pattern $=\& s t B y V a \mid=1 \& p 1=1 \& p 2=-1 \&$ tabMode $=$ dataTable \&csid $=$

29. Public Health Agency of Canada: Perinatal Health Indicators for Canada 2011. Ottawa:; 2012 [http://www.phac-aspc.gc.ca/rhs-ssg/phi-isp-2011-eng.php]

30. Greenberg CR, Dilling LA, Thompson GR, Seargeant LE, Haworth JC, Phillips S, Chan A, Vallance HD, Waters PJ, Sinclair G, Lillquist Y, Wanders RJA, Olpin SE: The paradox of the carnitine palmitoyltransferase type la P479L variant in Canadian Aboriginal populations. Mol Genet Metab 2009, 96:201-207.

31. Statistics Canada: Table 102-4512 - Live births, by weeks of gestation and sex, Canada, provinces and territories, annual, CANSIM (database).; 2012 [http:// www5.statcan.gc.ca/cansim/a26?lang=eng\&retrLang=eng\&id=1024512\&paSer= \&pattern $=\&$ stBy $V a \mid=1 \& p 1=1 \& p 2=-1 \&$ tabMode $=$ dataTable \&csid $=$

32. Macaulay A, Orr P, Macdonald S, Elliott L, Brown R, Durcan A, Martin B: Mortality in the Kivalliq Region of Nunavut, 1987-1996. Int J Circumpolar Health 2004, 63(Suppl 2):80-85.

33. Freemantle CJ, Read AW, De Klerk NH, McAullay D, Anderson IP, Stanley FJ: Patterns, trends, and increasing disparities in mortality for Aboriginal and non-Aboriginal infants born in Western Australia, 1980-2001: population database study. Lancet 2006, 367:1758-1766

34. Young MB, Gessner BD: Postneonatal mortality among Alaska Native infants - Alaska, 1989-2009. MMWR Morb Mortal Wkly Rep 2012, 61:1-5.

35. Ekho N, Ottokie U: Interviewing Inuit Elders: Childrearing Practices. 1st edition. Iqaluit: Nunavut Arctic College; 2000:3.

36. Peters S, Cowan J, Osborne G, Sobol I, Arbour L: Rates of hospitalization for lung infection of Inuit infants from the Baffin Region and association with heart defects 2000-2005. Circumpolar Health Supp/ 2010, 7:258-262.
37. Banerji A, Greenberg D, White LF, Macdonald WA, Saxton A, Thomas E, Sage D, Mamdani M, Lanctôt KL, Mahony JB, Dingle M, Roberts A: Risk factors and viruses associated with hospitalization due to lower respiratory tract infections in Canadian Inuit children: a case-control study. Pediatr Infect Dis J 2009, 28:697-701

38. Kovesi TA, Cao Z, Osborne G, Egeland GM: Severe early lower respiratory tract infection is associated with subsequent respiratory morbidity in preschool Inuit children in Nunavut, Canada. J Asthma 2011, 48:241-247.

39. Kovesi T, Creery D, Gilbert NL, Dales R, Fugler D, Thompson B, Randhawa N Miller JD: Indoor air quality risk factors for severe lower respiratory tract infections in Inuit infants in Baffin Region, Nunavut: a pilot study. Indoor Air 2006, 16:266-275

40. Zulz T, Bruce M, Parkinson A: International Circumpolar Surveillance: Prevention and Control of Infectious Diseases: 1999-2008. Circumpolar Health Suppl 2009, 4:20-23.

41. Tomashek KM, Shapiro-Mendoza CK, Davidoff MJ, Petrini JR: Differences in mortality between late-preterm and term singleton infants in the United States, 1995-2002. J Pediatr 2007, 151:450-456.e1.

42. Kramer MS, Demissie K, Yang H, Platt RW, Sauvé R, Liston R: The contribution of mild and moderate preterm birth to infant mortality. Fetal and Infant Health Study Group of the Canadian Perinatal Surveillance System. JAMA 2000, 284:843-849.

43. Mehaffey K, Higginson A, Cowan J, Osborne GM, Arbour LT: Maternal smoking at first prenatal visit as a marker of risk for adverse pregnancy outcomes in the Qikiqtaaluk (Baffin) Region. Rural Remote Health 2010, 10:1484.

44. Public Health Agency of Canada: Canadian Perinatal Health Report. 2008th edition. Ottawa:; 2008 [http://www.phac-aspc.gc.ca/publicat/2008/cphr-rspc/ index-eng.php]

45. Bonnefont J-P, Demaugre F, Prip-Buus C, Saudubray JM, Brivet M, Abadi N, Thuillier L: Carnitine palmitoyltransferase deficiencies. Mol Genet Metab 1999, 68:424-440.

46. Statistics Canada: Table 051-0053 - Components of population growth by census division, sex and age group for the period from July 1 to June 30, based on the Standard Geographical Classification (SGC) 2006, annual (persons), CANSIM (database):; 2012 [http://www5.statcan.gc.ca/cansim/a26?lang= eng\&retrLang=eng\&id=0510053\&paSer=\&pattern=\&stBy Val=1\&p1=1\&p2= $-1 \&$ tabMode=dataTable\&csid=]

47. Guntheroth WG, Spiers PS: The triple risk hypotheses in sudden infant death syndrome. Pediatrics 2002, 110:e64.

48. Luo Z-C, Wilkins R, Kramer MS: Effect of neighbourhood income and maternal education on birth outcomes: a population-based study. CMAJ 2006, 174:1415-1420.

49. Egeland GM, Pacey A, Cao Z, Sobol I: Food insecurity among Inuit preschoolers: Nunavut Inuit child health survey, 2007-2008. CMAJ 2010, 182:243-248.

50. Lauson S, McIntosh S, Obed N, Healey G, Asuri S, Osborne G, Arbour L: The development of a comprehensive maternal child health surveillance system for Nunavut-Nutaqqavut (Our Children). Int I Circumpolar Health 2011, 70(4):363-372

doi:10.1186/1471-2431-12-190

Cite this article as: Collins et al:: Causes and risk factors for infant mortality in Nunavut, Canada 1999-2011. BMC Pediatrics 2012 12:190.

\section{Submit your next manuscript to BioMed Central and take full advantage of:}

- Convenient online submission

- Thorough peer review

- No space constraints or color figure charges

- Immediate publication on acceptance

- Inclusion in PubMed, CAS, Scopus and Google Scholar

- Research which is freely available for redistribution 